Article

\title{
Sustainable Education in the Context of COVID-19: Study of the Social Perception and Well-Being of Students at the Faculty of Engineering in Sibiu, Romania
}

\author{
Lucian-Ionel Cioca (D) and Mihaela Laura Bratu*
}

Citation: Cioca, L.-I.; Bratu, M.L. Sustainable Education in the Context of COVID-19: Study of the Social Perception and Well-Being of Students at the Faculty of Engineering in Sibiu, Romania. Sustainability 2021, 13, 12805. https://doi.org/10.3390/su132212805

Academic Editor: Jordi Colomer Feliu

Received: 4 October 2021

Accepted: 15 November 2021

Published: 19 November 2021

Publisher's Note: MDPI stays neutral with regard to jurisdictional claims in published maps and institutional affiliations.

Copyright: (c) 2021 by the authors. Licensee MDPI, Basel, Switzerland. This article is an open access article distributed under the terms and conditions of the Creative Commons Attribution (CC BY) license (https:// creativecommons.org/licenses/by/ $4.0 /)$.
Department of Industrial Engineering and Management, Faculty of Engineering, Lucian Blaga University of Sibiu, 550024 Sibiu, Romania; lucian.cioca@ulbsibiu.ro

* Correspondence: laura.bratu@ulbsibiu.ro; Tel.: +40-745-376-880

\begin{abstract}
The COVID-19 pandemic has had global effects on all industries and on people around the world. The COVID-19 pandemic has had repercussions both politically and economically, as well as on society and the individual, i.e., on the human psyche. Although the effects on the human psyche have been highlighted in research, the well-being of the individual in correlation with social perception have not been addressed in this context but in different situations. The review of the relevant literature has also identified a knowledge gap concerning online vs. face-to-face learning, from the perspective of psychological, pedagogical and managerial factors. The present study aims to address the relationship of well-being-social perception-academic performance during the COVID19 pandemic on a group of students from the Faculty of Engineering in Sibiu, Romania. Three types of instruments were used to evaluate the studied characteristics: the Warwick Edinburgh Mental Well-being Scale (WEMWBS), the SKS method for generating feedback and the grid for assessing knowledge. The results showed the increase of the three parameters studied, after quarantine. The conclusions of the research are that, despite the greater variation in mood, caused by stress, anxiety and tension, the well-being of the subjects increased and the positive feedback provided increased significantly. The results lead to the formation of a positive self-image of students, which also has an impact on learning outcomes.
\end{abstract}

Keywords: COVID-19; well-being; social perception; university sustainability; feedback; self-image

\section{Introduction}

Coronaviruses are a family of viruses that can cause respiratory infections, common colds or more severe diseases in humans and animals. The best-known respiratory infections caused by coronaviruses are Middle East Respiratory Syndrome (MERS), Severe Acute Respiratory Syndrome (SARS) and the coronavirus discovered in 2019-COVID-19.

The COVID-19 pandemic has had a global impact on all people and sectors of activity, primarily due to restrictions on the mobility of governments and institutions to maintain social distance [1]. Recent research has highlighted the impact of COVID-19 on use of technology and the internet [1-4], economy [5], food industry [6,7], environment [8-10], urbanization [11], people's lifestyle [12] and professional life [13-15] and physical and mental health of the population [16-22].

The pandemic causes strong attitudes and emotions in the population. People oscillate between caution [2], stigma and social exclusion [16], distrust of state authorities as sources of information on the pandemic [6], fear, anxiety, stress, violence [14,17,20,23], decreased intimacy, social contacts and the individual emotional impact caused by death and loneliness [13,19]. Social isolation has led to increased dependence on substances [18]. At the level of activity sectors, there were positive effects, such as democratization of certain services [4] and positive impact on the environment [8,9], but also negative effects [10], such as highlighting the 
positive aspects of change in people's lives and extending them to post-pandemic life [3] and detached observation of some elements, from a new perspective [12].

From the information presented above, a polarization of the pandemic effects can be observed, within the analyzed subjects, the impact being both positive and negative in the same observed sector.

At the level of the human psyche, social isolation has produced visible effects and changed the lives of all social categories [24]. Social isolation at home has changed the dynamics of the family [25,26], the mental health of family members [27] and the desire for solitude [28], and has led to complex problems in the behavior of individuals, families, communities and nations [29].

From the multitude of effects that the pandemic has on the human psyche, this paper aims to address the impact of COVID-19 on the well-being and social perception of a group of students at the Faculty of Engineering, Sibiu.

One of the measures taken by governments during the pandemic was to close educational institutions. This measure has had an impact on the lives of youth, who are concerned about the repercussions and educational prospects. At the same time, online education has caused communication problems: young people have expressed the need for information to be clear, concise, easy to understand and easily accessible [30]. One limitation of online education was the passive nature of learning, rather than active participation.

The first concept analyzed in the research, well-being, is widely used in the present. The definition of the concept varies depending on gender, age, cultures, communities and countries. Well-being has been defined by the individual characteristics of an inherently positive state (happiness); it has also been defined on a continuum from positive to negative, such as how a person would appreciate self-esteem, or in terms of the context of a person (standard of living), lack of well-being (depression) or within a group (interrelationship) [31].

Factors that determine well-being [32] are the following: perception of control vs. assessment of predictable and stable nature, emotional intelligence, self-acceptance and self-esteem, personality type, positive behavior of the superior, politeness, emotional abuse, burnout and physical and mental health [33].

At the educational level, well-being determines satisfaction in learning, increases motivation, reduces illness, decreases absenteeism, decreases accidents, increases the quality and efficiency of teaching and learning and increases the productivity transposed in school results [32,34].

The second concept analyzed in the research is the social perception of students, manifested in the feedback provided on the teaching act, before the pandemic and after the lockdown.

Social perception is a segment of the cognitive process through which the individual comes to form an image of themself and at the same time, depending on how impressions are shaped and appreciation of others. In this definition, there are two sides of the same phenomenon: the individual approaches another starting from themselves and the representation of another is part of the process of self-perception [35].

Social perception is the result of social observation, which is based on three elements: the people observed, the situations in which they find themselves and their behavior. Each of us has predetermined notions about certain types of situations-true 'scenarios' that allow us to anticipate the goals, behaviors and likely outcomes of a particular situation [36]. These predetermined notions and sets of values represent precisely the externalization of the self-image.

Feedback is a retroaction that manifests itself at the level of different systems (biological, technical, etc.) in order to maintain their stability and balance against external influences. Feedback is also a reverse retroaction, a reverse connection, a ring causation and a closed causal chain [37].

There is a whole culture of feedback, especially during the pandemic, as a means of connection between employees and managers. Two-way feedback, both from the manage- 
ment level (hierarchical boss) to employees, and vice versa, from employees to hierarchical superiors, encourages a transparent, appreciative work climate and will constantly improve the organizational culture and results of the organization [38].

In higher education, feedback serves a variety of purposes, including the grading of achievements and the development of students' understanding, skills and motivation [39]. Feedback is an intentional dialogue between the teacher and student, with each person involved in education having a significant role. Students must be willing and able to provide feedback to teachers not only about their learning needs, but also about the teaching they experience. In turn, teachers need to create the conditions that support active student learning. The feedback provided involves both teachers and students to reconceptualize their roles in teaching, learning and assessment [40].

Feedback is the intervention with the greatest educational impact, the highest scalability and the lowest implementation cost, according to the ranking made by the international expert in education sciences John Hattie [41]. The ranking of impactful educational interventions in education can be made according to several indicators: efficiency, strength of scientific evidence, costs, impact and scalability [41]. Feedback holds the first place regarding successful educational interventions, followed by the teacher-student relationship, metacognitive strategies and collaborative learning [41].

When the feedback required from students on the teacher is subjective, without being oriented towards a certain segment of the teaching act and without being directed, guided by a formal framework, it reflects not only the personality and personal values [42,43], but especially the social perception of the respondent.

It is observed that, from a psychological point of view, well-being and social perception have as a common element the self-image. Self-image is a social construction: we are formed by belonging to a social group, by comparison with others, and we are influenced by a social situation or by some personalities in the social environment. Self-image contains knowledge about our personality traits, abilities and skills and values, beliefs, motivations, life events and relationships with others, which exert a significant influence. To describe the self-image of the individual, psychologists also use the concept of self [44].

Self-image contributes to the assessment of reality [45], and thus, implicitly, the feedback provided and well-being is an assessment of reality.

The paper aims to analyze the assessment of reality by a group of students from the Faculty of Engineering, Sibiu, by assessing their well-being and the feedback provided during the COVID-19 pandemic. The purpose of the research is to observe the characteristics of school results-learning productivity, well-being and feedback provided by a group of students from Sibiu, Romania, during the pandemic, as well as the relationship between these concepts.

Both analyzed concepts, well-being and feedback, are characterized in terms of productivity, efficiency. Both high well-being and feedback are indicators of productivity and correlate directly with it $[32,34,38,39]$. However, the evolution of these concepts-feedback, well-being and performance, correlated with the impact of the pandemic on the human psyche and online learning-has not been studied so far.

At the level of university education, student productivity translates into learning efficiency, which is directly reflected in school results. Until recently, the desideratum of all organizations and sectors of activity was efficiency, the ratio between the effort made and the results obtained [33]. Currently, based on the United Nations Conference on Environment and Development, a concept on the desideratum of efficiency has been introduced: sustainability. Sustainability is the development that meets the needs of the present, without compromising the ability of future generations to meet their own needs [46]. The United Nations has included sustainability on its list of priorities since 1992, and in 2018, it resumed the idea of sustainability, associated with climate change [47]. A migration of specialists' concerns can be observed from efficiency-effort-results to resources-results. Initially, sustainability was related only to environmental resources, addressing various issues, such as ecology and environmental protection management [48,49], forest management [50], soil management [51] 
and agricultural science management [52]. At present, the scope of the notion of sustainability has extended to the social [53] and educational [54] environment.

The analysis of students' mental state, related to the individual resources of students and teachers, leads to an educational system that is not only efficient, but sustainable; a system that analyzes resources and behaves flexibly to achieve the desired results.

Figure 1 summarizes the key research terms. Well-being and feedback reflect the person's self-image, and the grades obtained in the semester assessment are an indicator of personal efficiency in learning, as well as the sustainability of the university education system.

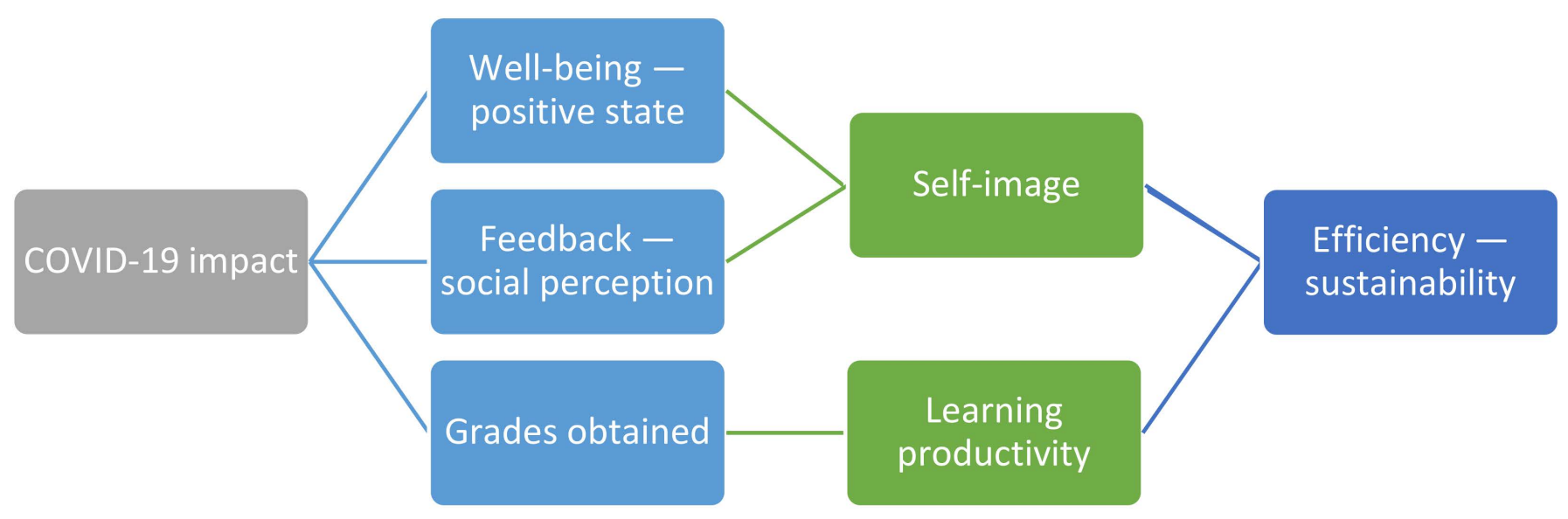

Figure 1. Key research terms.

The three key research terms identified above are analyzed both before quarantine, when university activity was face-to-face, and after quarantine, during online learning.

The migration of the teaching-learning activity exclusively in the online environment during the pandemic determined the adaptation of the methods and means used in teaching-learning evaluation, as well as of the communication and management strategies. Online and face-to-face teaching-learning methods have distinct characteristics [55-58], especially for disciplines that require practical work.

The two learning environments involve students and teachers differently in sharing ideas and identities [59] and produce different results [55]. Online learning has a great effect in reducing negative emotions and increasing commitment and has a moderate effect on the growth of positive affection [60]. In terms of learning styles, face-to-face system learning promotes a tactile learning style, while online learning promotes the visual learning style [61,62].

From the perspective of the sustainability of university education, the online environment also brings a number of benefits: lower budgets [61], increased efficiency [63] and program flexibility [61,62].

Even if there are people or communities who prefer face-to-face activity [64], there is research that has shown that the blending variant, a mix between physical and online [65,66], due to efficiency, benefits the emotional life and social development of the individual.

In brief, the COVID-19 pandemic has had effects on the mental and physical condition of the population [16-29]. Although the effects on the human psyche have been highlighted in the research [12-29], it is observed that the well-being of the individual in correlation with social perception were not addressed in this context but in different situations. The review of the relevant literature has also identified a knowledge gap concerning online vs. face-to-face learning, from the perspective of psychological, pedagogical and managerial factors. Thus, the present study aims to address the relationship of well-being-social perception-academic performance during the COVID-19 pandemic.

Following the analysis of the literature mentioned above, it is observed that there are studies on the well-being of students, as well as the feedback provided by them and 
school results, but the three concepts have not been addressed simultaneously in one research study. This gap identified in the literature justifies the present study. Moreover, the concepts have not been addressed during the COVID-19 pandemic so far. The data obtained were collected during the beginning of the lockdown, when the vast majority of the world did not anticipate what the impact that the pandemic would be on society as a whole. Because humanity has not faced a pandemic of such magnitude in the last century, mapping the features of a large group of people, including a group of young people in Romania, can provide information on the human psyche in extreme situations.

The present research focused on the request for qualitative feedback from students, in order to outline the real needs of students regarding the teaching act. Currently, feedback is required on forms related to teacher evaluation criteria, in which students only give grades and tick predefined boxes. The form is not organized according to the students' needs, an innovative aspect brought by the study by identifying some clusters to which the students refer in the evaluation.

At the same time, the study brings as a novelty the discussion on the pedagogical and psychology factors involved in teaching and their weight and evolution in the physical environment, compared to the online environment. It is appropriate to characterize teaching and learning in the online environment, in order to improve and preserve in the future all the positive elements observed during the activity during the pandemic.

The research hypothesis is as follows:

Hypothesis 1 (H1): The quarantine caused by the COVID-19 pandemic produces changes in the well-being and social perception of students, as well as in the school results obtained.

The second general hypothesis is the following:

Hypothesis 2 (H2): The psychological, pedagogical and managerial factors involved in teaching are modifying in the online environment compared to face-to-face learning.

In conclusion, the study aims to assess the impact of the COVID-19 pandemic on selfimage and verify the extent to which it is directly reflected in school results. Self-image will be analyzed in terms of well-being and feedback provided, as a component of social perception.

The purpose of the research is to evaluate the changes produced in the well-being of students, the characteristics of the feedback provided on the activity of the teacher, as well as the school results, under the impact of quarantine during the COVID-19 pandemic.

The objectives of the study are the following:

1. Assessment and analysis of students' well-being before and after quarantine during the COVID-19 pandemic.

2. Analysis of the feedback provided by students on the activity of the teacher, before and after quarantine.

3. Analysis of learning outcomes of the group before and after quarantine.

4. Comparative analysis of data obtained from the three categories analyzed: well-being, feedback and learning outcomes.

5. Analysis of the educational process from the perspective of the learning environment: face-to-face and online.

\section{Materials and Methods}

\subsection{Overview}

The research was carried out during two semesters of the academic year 2019-2020. Initially, three items were evaluated, i.e., well-being, feedback and grades obtained in February 2020, as compared to the first semester. At the beginning of February 2020, there were very few cases of COVID-19 in Europe, and in the media, the subject was still considered unimportant or ironic. 
In mid-March, Romania entered quarantine, as the first radical measure in the fight against COVID-19, and the activity of universities moved exclusively to the online environment. The retesting stage of the researched items took place in May-June, after the quarantine was lifted.

Thus, the research was carried out in two stages:

1. Stage 1-February 2020: Assessing the well-being of students and providing feedback on the face-to-face activity carried out in the first semester of the academic year 2019-2020. Evaluating learning outcomes for the specified group.

2. Stage 2-May-June 2020: Assessing the well-being of students and providing feedback on the online activity carried out in the second semester of the academic year 2019-2020. Evaluating learning outcomes for the specified group.

We mention that at Lucian Blaga University of Sibiu, Romania, the structure of the academic year 2019-2020 was as follows: the first semester was between 1 October 201916 February 2020 and the second semester was between 24 February 2020-19 July 2020.

The first state of emergency (quarantine) established throughout the country was between March and May 2020.

\subsection{Participants}

Research population for this study is the youth studying at Faculty of Engineering from Sibiu, Romania. The population sampling was done involving all students who participated in the courses of a single teacher and who expressed their free consent, namely 61 students. Table 1 describes the characteristics of the investigated sample.

Table 1. Sample structure.

\section{Sample Structure}

\footnotetext{
. 44 of the subjects are female and 17 male.
}

. 59 have the appropriate school age related to the level of study (20-25 years), and 2 have ages between 40 and 42 years.

- 50 follow the faculty courses, level I, and 11 follow a master's degree, level II, in the bologna system.

- 26 have a job, and they have been working between 0 and 2 years (22).

. 44 still live with their parents.

The students were informed about the objectives and methodology of the research and expressed their informed consent.

\subsection{Materials}

\subsubsection{Assessment of Well-Being}

The Warwick Edinburgh Mental Well-being Scale (WEMWBS) was used to assess students' well-being. The WEMWBS is a scale that includes 14 items that assesses mental state and well-being, ranging from 1-never to 5-always. The minimum score is 14 and the maximum score is 70. In Scotland, this score averaged 50.7 [67].

The variant used is the one from 2006, which was translated after the short version into Romanian, with seven questions, from 1998, according to the translation grid present on the site where the questionnaire was taken from [67]. For the translation of the questionnaire, the guide written by the International Test Commission was used as a bibliographic source [68]. Permission was obtained to use the questionnaire from the University of Warwick, which participated in the development of the scale [69].

In the first stage, conducted before the pandemic, the WEMWBS scale was given on paper, which was answered anonymously, and in the second stage, conducted online, the questions were asked in a Google Forms, for which students also remained anonymous. 


\subsubsection{Evaluating the Feedback Provided by Students}

The feedback provided by the students was done using the SKS method: stop (S), keep (K) and start (S) [70]. Philip Daniels, a professor at Brigham Young University, found the following questions efficient for asking feedback from others [70]:

1. What else should I give up?

2. What should I continue to do?

3. What should I start doing?

The best way to optimize your business in all areas is to ask for negative feedback. The SKS method is excellent, because the negative feedback is provided indirectly, masked and helps to anchor in reality the evaluated person, in the sense of creating a self-image in line with reality. Both negative and positive feedback were requested through the three questions.

The SKS method is often used in the process of faculty evaluations at universities, as well as performance appraisals on Wall Street [71].

The students answered the three questions anonymously, having no other additional landmarks and being able to answer freely, from any perspective they considered. In the first stage, conducted before the pandemic, the answers were written on paper, and in the second stage, conducted online, the questions were asked in a Google Forms, to which they also answered anonymously.

The research approach based on the SKS method is qualitative, so the answers to the questions were quite difficult to interpret. After a thorough reading of the answers, four general categories were established to which the students referred in the feedback provided, according to Table 2, and the answers were grouped into four dimensions, hereinafter referred to as clusters. All data obtained with the SKS method were analyzed on clusters.

Table 2. Feedback evaluation clusters.

\begin{tabular}{|c|c|c|}
\hline No. & Clusters & Items \\
\hline \multirow{3}{*}{1.} & \multirow{3}{*}{ Psychological } & $\begin{array}{l}\text { Personality, including temperament, skills, } \\
\text { character, creativity }\end{array}$ \\
\hline & & $\begin{array}{l}\text { Social relationships, including language, } \\
\text { communication, motivation, group psychology }\end{array}$ \\
\hline & & Personal Development \\
\hline \multirow{2}{*}{2.} & \multirow{2}{*}{ Pedagogical } & Methods \\
\hline & & Content of learning \\
\hline 3. & Educational management & Program, conflict \\
\hline \multirow{2}{*}{4.} & \multirow{2}{*}{ Global evaluation } & Everything is perfect \\
\hline & & I don't know you; I don't know \\
\hline
\end{tabular}

Cluster 4, the global evaluation, appeared in the stop and start assessments, questions 1 and 3. The masked negative feedback that had to be provided was turned by some students into extreme opinions: either they said everything was perfect, or they said they did not know the teacher well enough or they just did not know.

All student responses were given a score: +1 , for those with positive feedback, and -1 , for negative feedback. For the global assessment cluster, the answer "I don't know you, I don't know" was scored negatively, with -1 . The answers were analyzed both as an absolute value, in the mode, so without taking into account the type of feedback, following the frequency of choosing a particular cluster, and also as dichotomous values, +1 and -1 , to highlight the frequency of positive and negative feedback. 


\subsubsection{Evaluation of Learning Outcomes}

Both in the first stage, before the pandemic, and after the quarantine, the evaluation of the students was done through a test with nine open-ended questions, from the studied subjects. In the first stage, the evaluation took place face-to-face at the faculty, while in the second stage, it took place in an online environment, through the Google Meet platform.

\section{Results}

In the first stage of testing, the average value of the students' well-being was 53.9.

Analyzing the average values of the scores obtained for each question, according to Table 3, it can be observed that the most common problem of the subjects in the sample is the lack of reserve energy and lack of relaxation.

Table 3. Analysis of the answers to the WEMWBS scale questions in stage I.

\begin{tabular}{|c|c|c|}
\hline No. & Questions & $\begin{array}{c}\text { The Average Values of the Scores } \\
\text { Obtained for Each Question }\end{array}$ \\
\hline 1. & I was optimistic about the future & 3.83 \\
\hline 2. & I felt useful & 3.71 \\
\hline 3. & I felt relaxed & 3.45 \\
\hline 4. & I was interested in other people & 3.75 \\
\hline 5. & I had spare energy & 3.33 \\
\hline 6. & I dealt well with the problems & 3.78 \\
\hline 7. & I thought clearly & 3.75 \\
\hline 8. & I felt good about myself & 4 \\
\hline 9. & I felt close to other people & 4 \\
\hline 10. & I felt confident & 3.8 \\
\hline 11. & $\begin{array}{l}\text { I managed to form my own opinion } \\
\text { on things }\end{array}$ & 4.11 \\
\hline 12. & I felt loved & 4.2 \\
\hline 13. & I was interested in new things & 4.15 \\
\hline 14. & I felt happy & 4.01 \\
\hline
\end{tabular}

The questions (Q) that obtained the highest scores are Q11, Q12 and Q13. The students stated that they felt loved, were interested in new things and had managed to form their own opinion about things.

In stage II of the testing, the average value of the students' well-being was 54.4.

Analyzing the average values of the scores obtained for each question, according to Table 4, it was observed that the most common problem of the subjects in the sample is a lack of relaxation. 
Table 4. Analysis of the answers to the WEMWBS scale questions in stage II.

\begin{tabular}{ccc}
\hline No. & Questions & $\begin{array}{c}\text { The Average Values of the Scores } \\
\text { Obtained for Each Question }\end{array}$ \\
\hline 1. & I was optimistic about the future & 3.91 \\
\hline 2. & I felt useful & 3.85 \\
\hline 3. & I felt relaxed & 3.40 \\
\hline 4. & I was interested in other people & 3.93 \\
\hline 5. & I had spare energy & 3.60 \\
\hline 6. & I dealt well with the problems & 3.73 \\
\hline 7. & I thought clearly & 3.75 \\
\hline 8. & I felt good about myself & 3.83 \\
\hline 9. & I felt close to other people & 4.03 \\
\hline 10. & I felt confident & 3.73 \\
\hline 11. & I managed to form my own opinion & 4.13 \\
\hline 12. & on things & 4.16 \\
\hline 13. & I felt loved & 4.24 \\
\hline 14. & I was interested in new things & 4.04 \\
\hline
\end{tabular}

The questions $(\mathrm{Q})$ that obtained the highest scores were identical to those in the first stage, Q11, Q12 and Q13. The students stated that they felt loved, were interested in new things and had managed to form their own opinion about things.

Regarding the feedback provided, both in stage I and in stage II, the following responses were recorded and grouped in the four clusters. The answers include both positive and negative feedback.

1. Psychological:

a. Personality - positive feedback: quiet, good, permissive, dreamy, organized, optimistic, positive, patience, calm, understanding, charismatic, cheerful, nice, passion, positive energy, creative ideas. Personality—negative feedback: too calm, too understanding, not in control, getting too angry when it is noisy.

b. Social relationships-positive feedback: communicating with people's souls, motivating people, bringing out the best in people, having close relationships with students, holding TED talk-like conferences related to creativity, understanding for fatigue and impatience, wanting to work with children. Social relationships-negative feedback: whether students can change (give examples of certain students), treating us like children, eliminating the feeling of friendship with students, imposing yourself, being tougher (authority: respecting the schedule, telling people to be quiet, banning phones, being more interested in colleagues).

c. Personal development-positive feedback: taking care of family and children, loving and appreciating the family, changing clothing style, working in this field because it suits you, writing journals, growing professionally and personally, feeling fulfilled, feeling special, reading or writing a book, looking at the world differently from other people, meditating, for balance and inner beauty, exploring the inner world, ideas and facts, doing new things which you did not do before, parachuting, starting something that you are passionate about but you gave up on it in the past. Personal development-negative feedback: to stop reporting to other teachers, smiling more, not relating to other teachers.

2. Pedagogical:

a. Methods-positive feedback: teamwork exercises, interactive, distinguished lessons, games, teamwork, auxiliary exercises, own examples, examples from books, teaching with enthusiasm, I like the teaching style, providing very good examples from real life, the teaching style is relaxing, interesting, attractive, you teach well, the methods help us in 
learning, they are easily understandable, they are interesting, attractive, easier to remember and accumulate, I want to listen to you, I want to learn from you, I want more games and coloring activities, to help us make us use our knowledge and creativity to solve problems, use of videos. Methods-negative feedback: we do not want individual homework, I work better in a team, the use of evaluation methods to take into account attendances, to be without a project, the teaching method is boring, methods based on drawing and coloring, official style to teach, not to involve students in speaking, even if they are tired, changing the way teams are formed, more diversified tone, more professional teaching method.

b. Contents-positive feedback: promoting Asian culture, combining literature with engineering and economics, teaching a technical subject because you have the necessary skills, supporting counseling classes, telling jokes and funny stories, telling us about the culture of other countries, giving more constructive ideas, which helps us in life. Contents-negative feedback: the restructuring of the presentations.

3. Educational management-positive feedback: you differentiate yourself from other teachers by originality. Educational management-negative feedback: give us a break during one seminar hour, because it is a long time and we need to be able to grab some water, the way you make observations to colleagues, schedule the lectures in the morning, I want to go home faster.

4. Overall assessment:

a. Everything is perfect.

b. I don't know you, I don't know.

Regarding the evaluation of students, in the first stage, the average grade was 7.18, and in stage II, the average grade was 8.34 .

\subsection{Assessment of Well-Being}

In the second stage of the assessment, the well-being of students increased by 0.5 , higher than the average recorded in stage I. A possible explanation for the increase in wellbeing after the pandemic could be the euphoria felt by people after lifting restrictions and regaining partial/total mobility, the assessment being made two weeks after the emergency was lifted.

However, as seen in Figure 2, the results obtained in the second stage tended to be extreme values, so the well-being of research participants deviated more from the average.

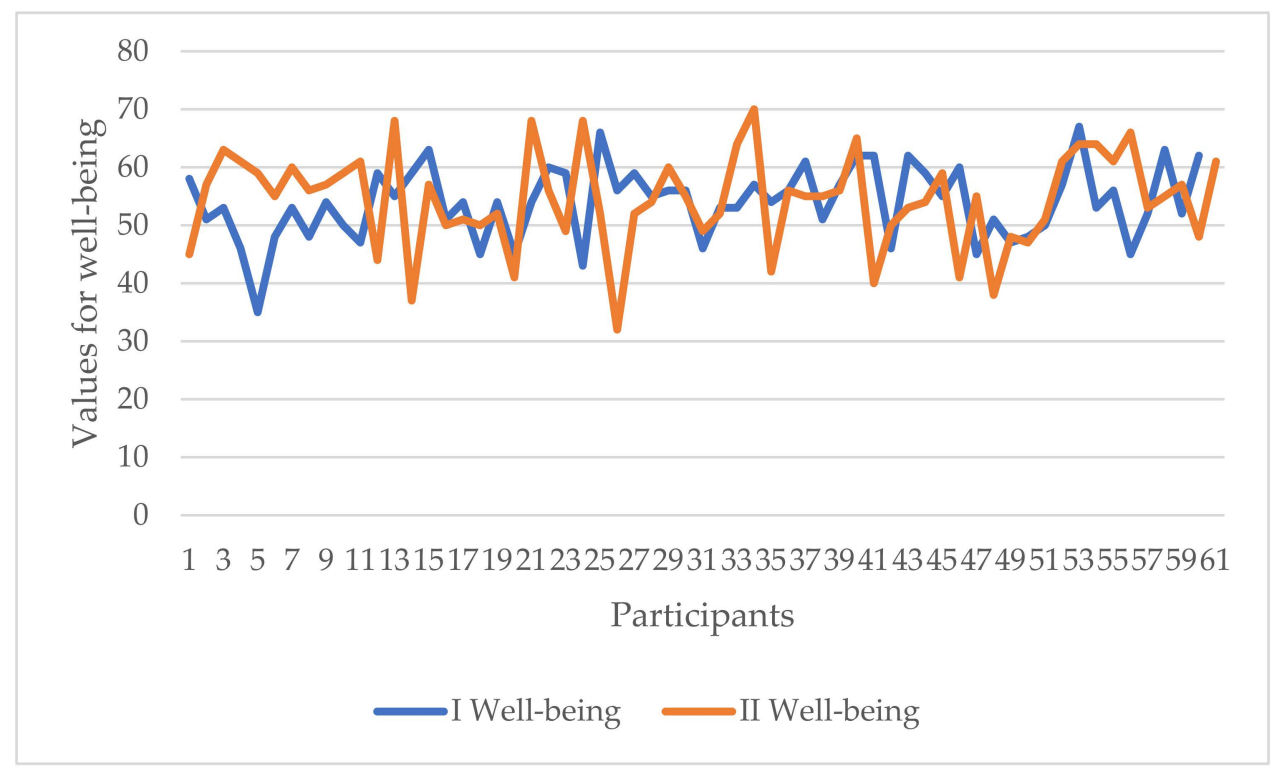

Figure 2. Analysis of the well-being evaluated during stage I compared with stage II. 
Figure 3 shows the analysis of the average scores for each question, both for stage I and for stage II.

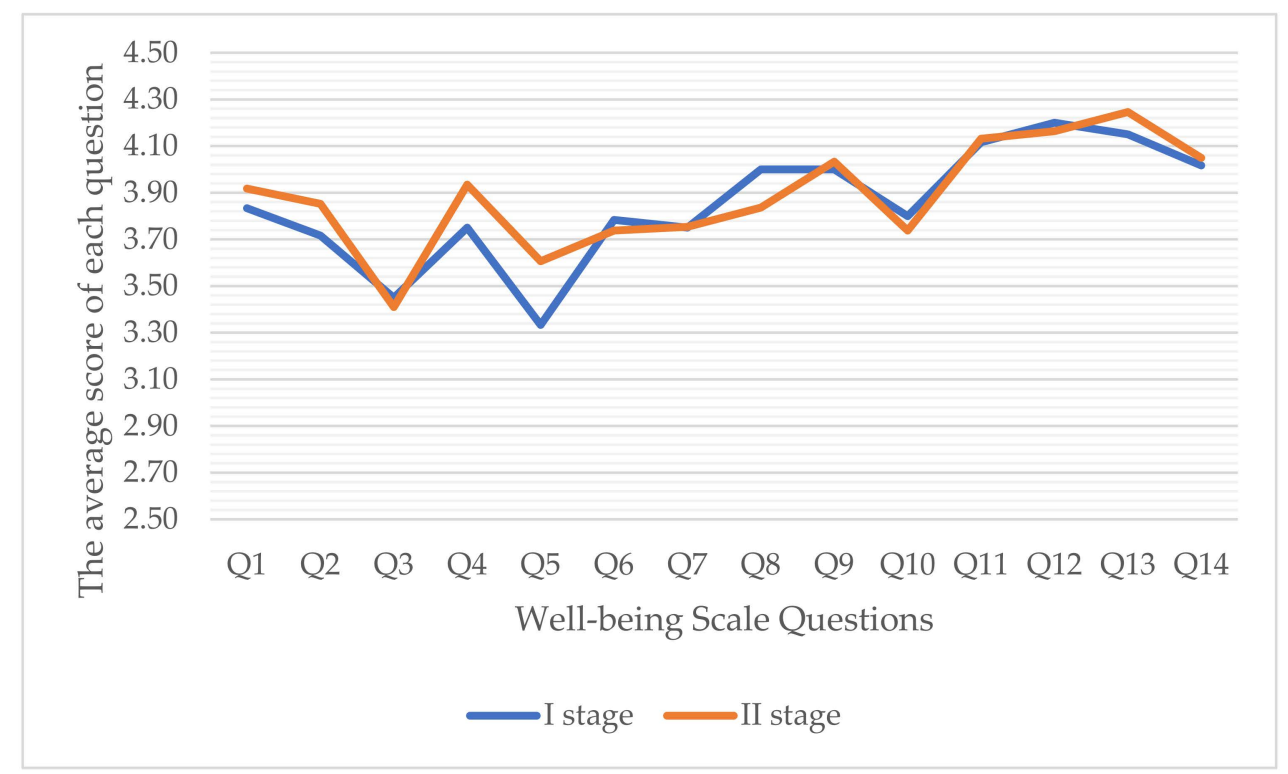

Figure 3. Analysis of the average score of each question, evaluated during stage I and stage II.

Figure 3 shows that, after the quarantine period, students' interest in other people increased, their energy level increased and their interest in new things also increased. On the other hand, the Q8 question showed the biggest drop, which shows that the students felt less comfortable with themselves. The scores for the questions Q3, Q6, Q10 and Q12 also registered a slight decrease. After the pandemic, the research participants were less relaxed, did not cope as well with the problems, were not as confident and did not feel as loved as before quarantine.

\subsection{Evaluating the Feedback Provided by Students}

The feedback offered by the students in stage I and in stage II of the research was analyzed comparatively, both on clusters and on the items of each cluster, for the absolute values, in mode, of the score, but also dichotomous, taking into account the type of feedback, i.e., +1 and -1 , corresponding to positive and negative feedback, respectively.

Figure 4 shows that for question Q1, "What should I stop doing before the pandemic", the students mainly analyzed the activity from a psychological and pedagogical point of view, while after the quarantine and, implicitly, after the online activity, the number of evaluations for the educational management cluster increased by $60 \%$ and the global evaluation increased by $360 \%$. Although after the quarantined online activity, the number of negative feedbacks in the dropout category, psychological and pedagogical, decreased, the decrease ratio was different: the evaluation of the psychological cluster decreased by $37 \%$, while for the pedagogical cluster, it decreased by $82 \%$. 


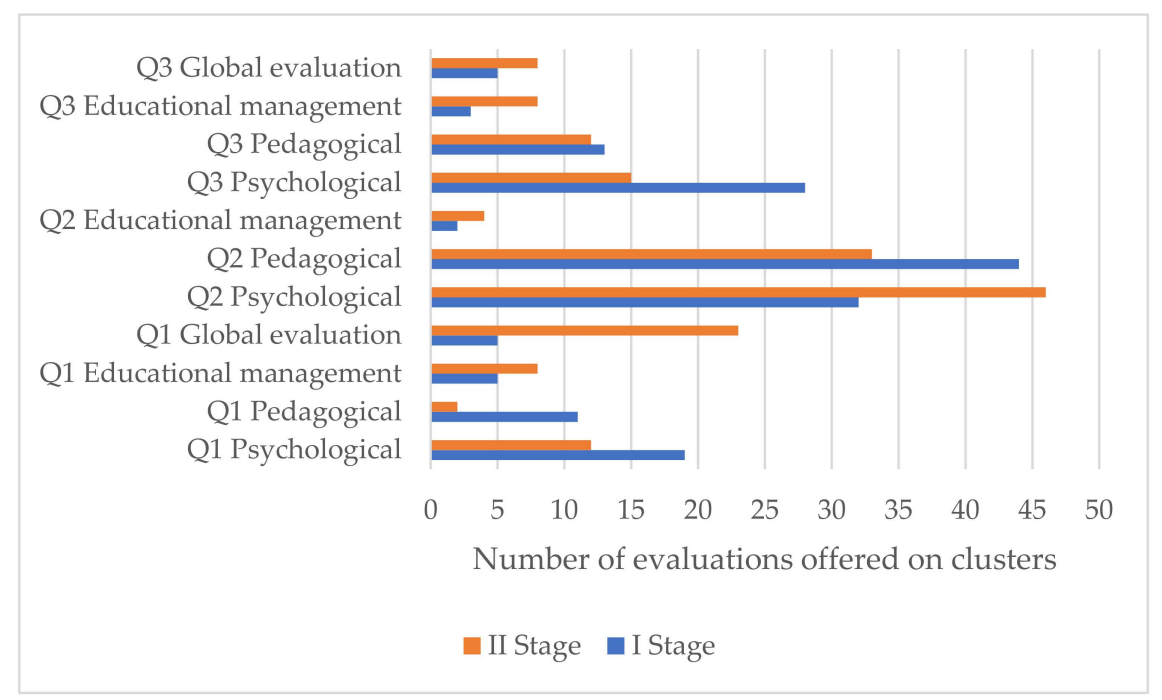

Figure 4. The results of the general feedback by clusters.

For the question Q2, "What should I continue to do", there is a change in perception after quarantine: in the online environment, the focus was mainly on the psychological cluster (increase by $44 \%$ ), to the detriment of the pedagogical one, which decreased by $25 \%$. There was also a slight increase in the feedback provided in terms of educational management, after quarantine.

For the Q3 question, "What should I start doing", the feedback decreased by $46 \%$ for the psychological cluster, but the number of nominations for the educational management and global evaluation clusters increased.

Figure 5 shows the positive feedback provided before and after quarantine. Responses from the negative feedback category which were in fact positive character traits were also included. Feedback for the psychological cluster increased by $16 \%$, while feedback on pedagogical issues decreased by $13 \%$. The positive evaluation of school management increased in stage II by $83 \%$, and the overall positive evaluation increased by $350 \%$.

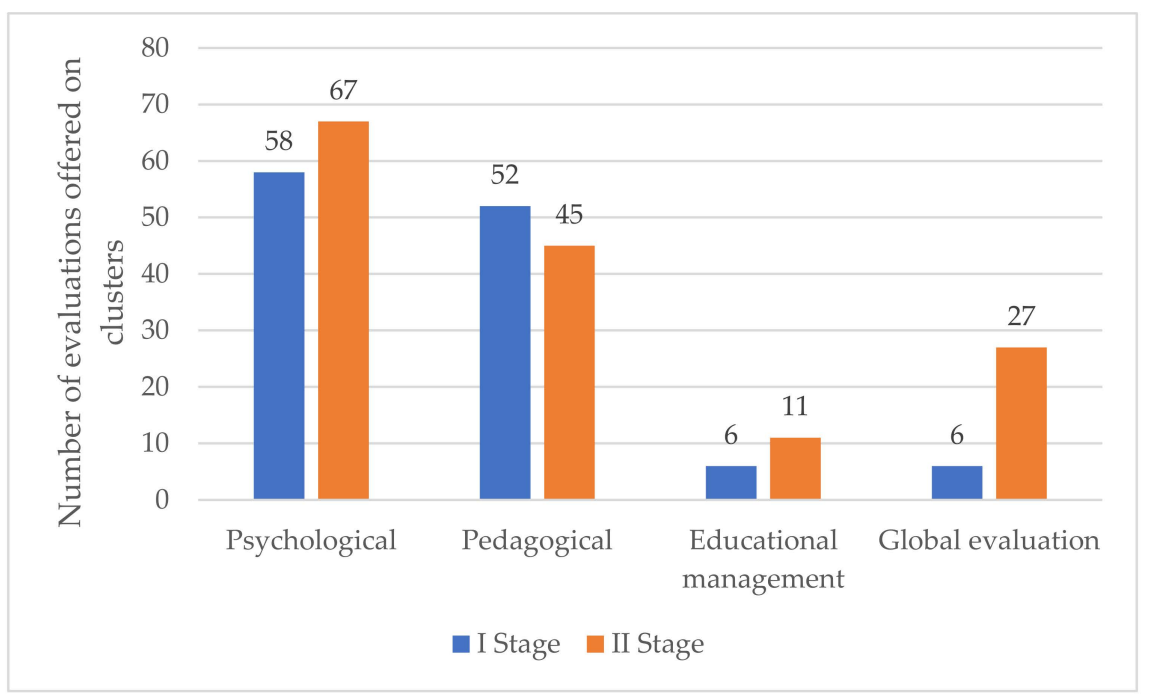

Figure 5. Positive feedback offered in stage I and II.

Figure 6 shows the negative feedback provided in stages I and II. Negative feedback is represented by questions Q1 and Q3. We mention that to the questions that asked for negative feedback, some of the subjects offered a masked positive feedback, statements that were punctuated with positive feedback, as mentioned above. The negative feedback 
for the psychological cluster decreased in stage II by $71 \%$, and the pedagogical one by $88 \%$. The overall negative assessment (I don't know, I don't know you) remained constant, but the negative feedback on educational management increased by $125 \%$. Analyzing the individual responses of the students, it was found that the explanation for the increase in negative feedback for the educational management cluster is the topics they had to post at each seminar.

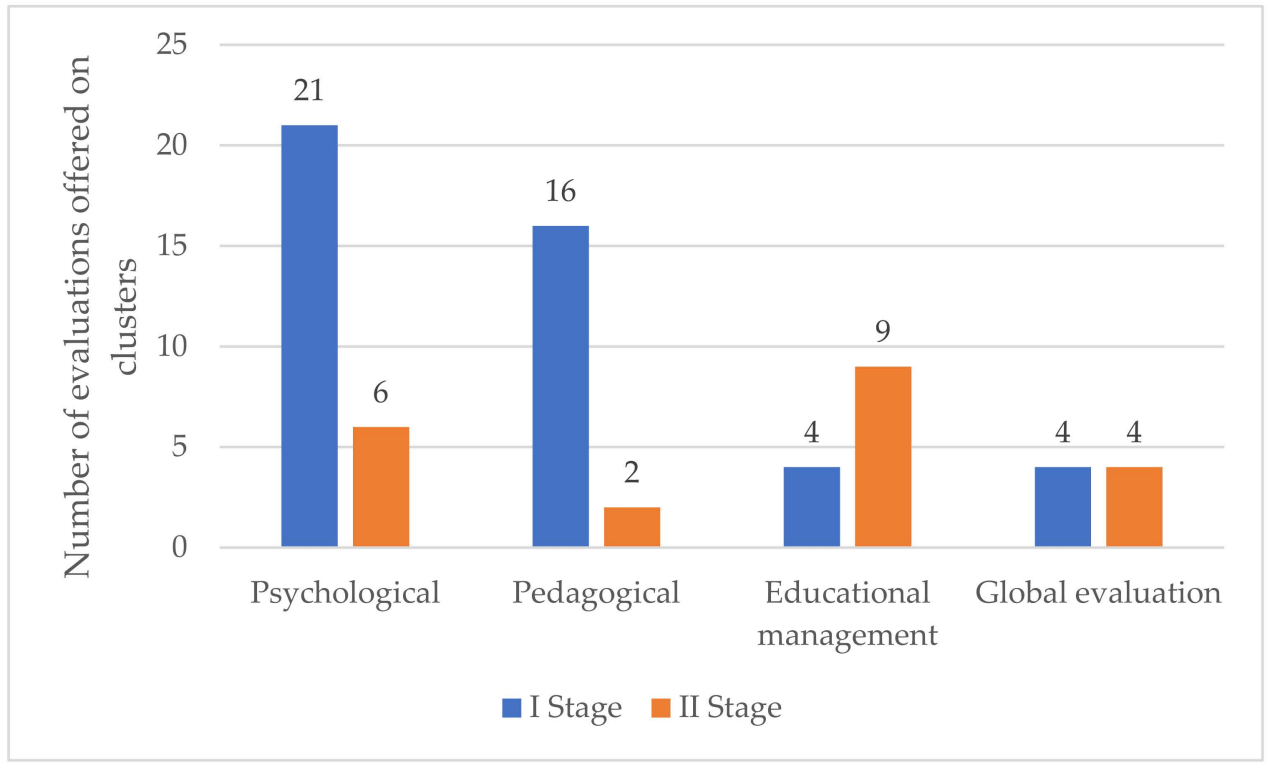

Figure 6. Negative feedback offered in stage I and II.

Regarding the analysis of the items of each cluster, the school management and the global evaluation have already been analyzed.

For the psychological cluster, the positive feedback remained constant before and after quarantine at the level of personality, but increased by $243 \%$ at the level of appreciation of social relations, as can be seen in Figure 7. The assessments regarding the personal development of the teacher decreased by $44 \%$.

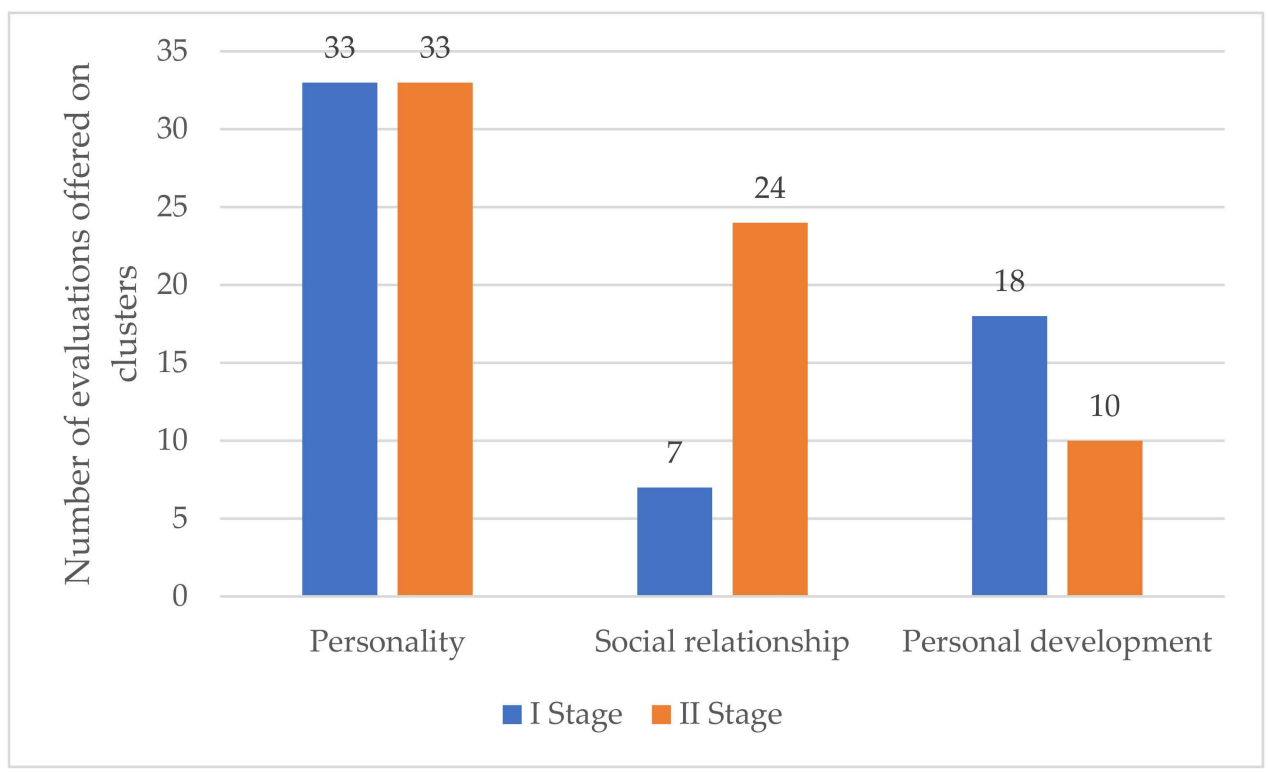

Figure 7. Positive feedback provided on the psychological cluster. 
Negative feedback for the psychological cluster is described in Figure 8. At the personality level, the negative feedback remained constant, while feedback on social relationships decreased by $83 \%$. No negative feedback was provided on issues related to the teacher's personal development.

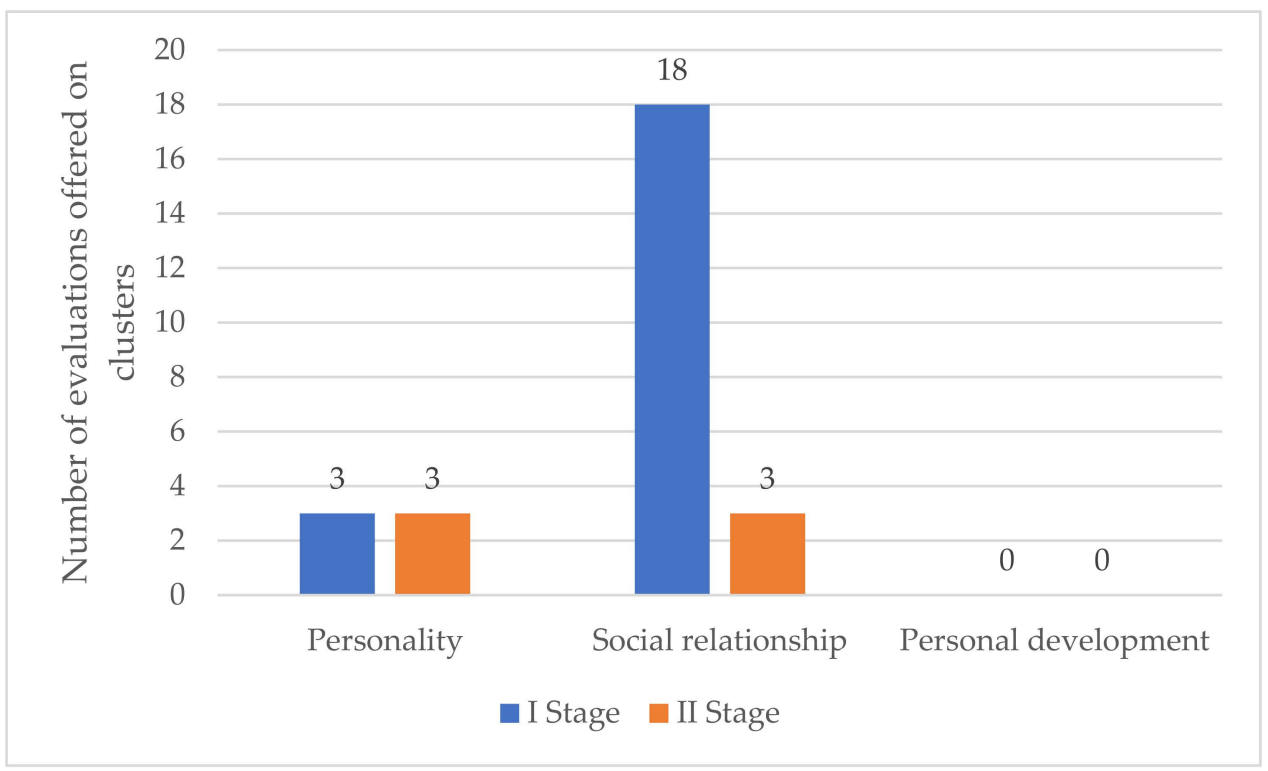

Figure 8. Negative feedback provided on the psychological cluster.

Regarding the feedback offered to the pedagogical cluster-methods, the positive one decreased by $16 \%$, and the negative one decreased by $93 \%$, according to Figure 9 . For the contents item, the feedback remained constant in both evaluation stages.

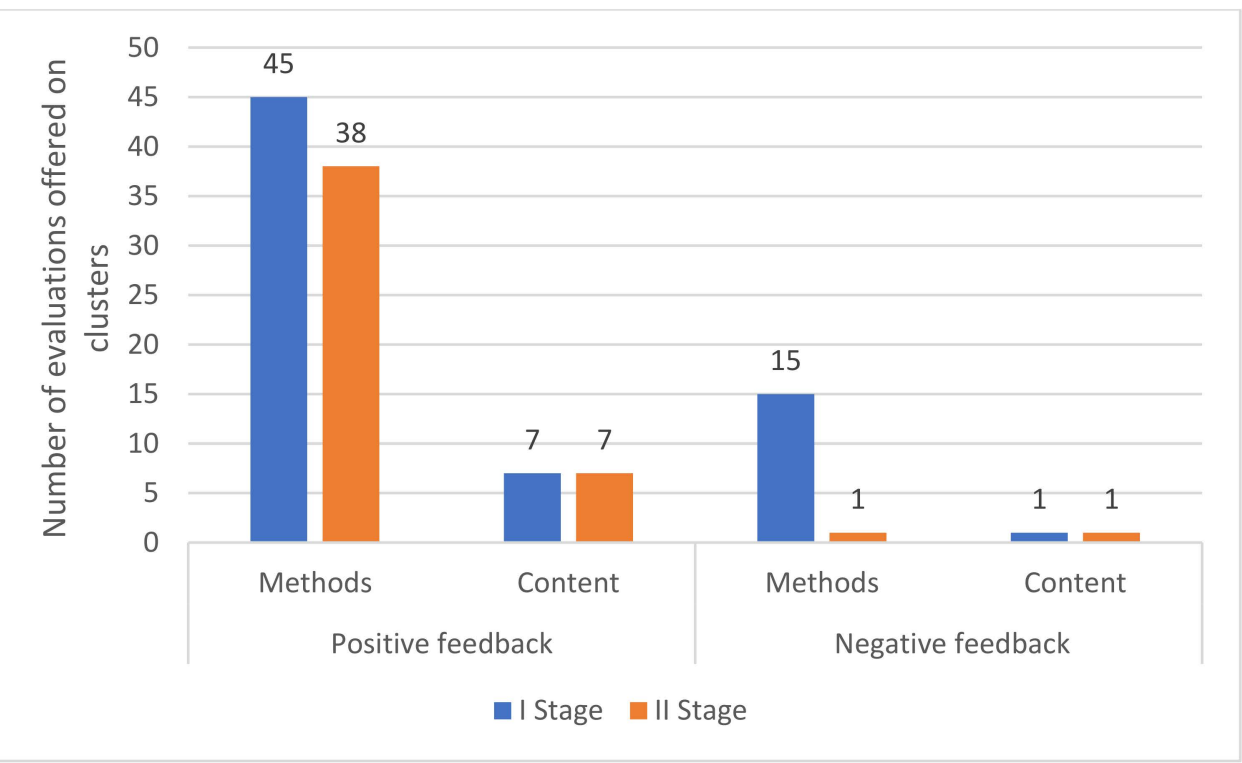

Figure 9. Analysis of the feedback in the pedagogical cluster.

\subsection{Evaluation of Learning Outcomes}

After analyzing the grades obtained by students before and after quarantine, according to Figure 10, there is a significant decrease in grades below 7 and an increase in high grades, especially grade higher than 8 . The average grade increased by 1.16 points, from 7.18 to 8.34 . 


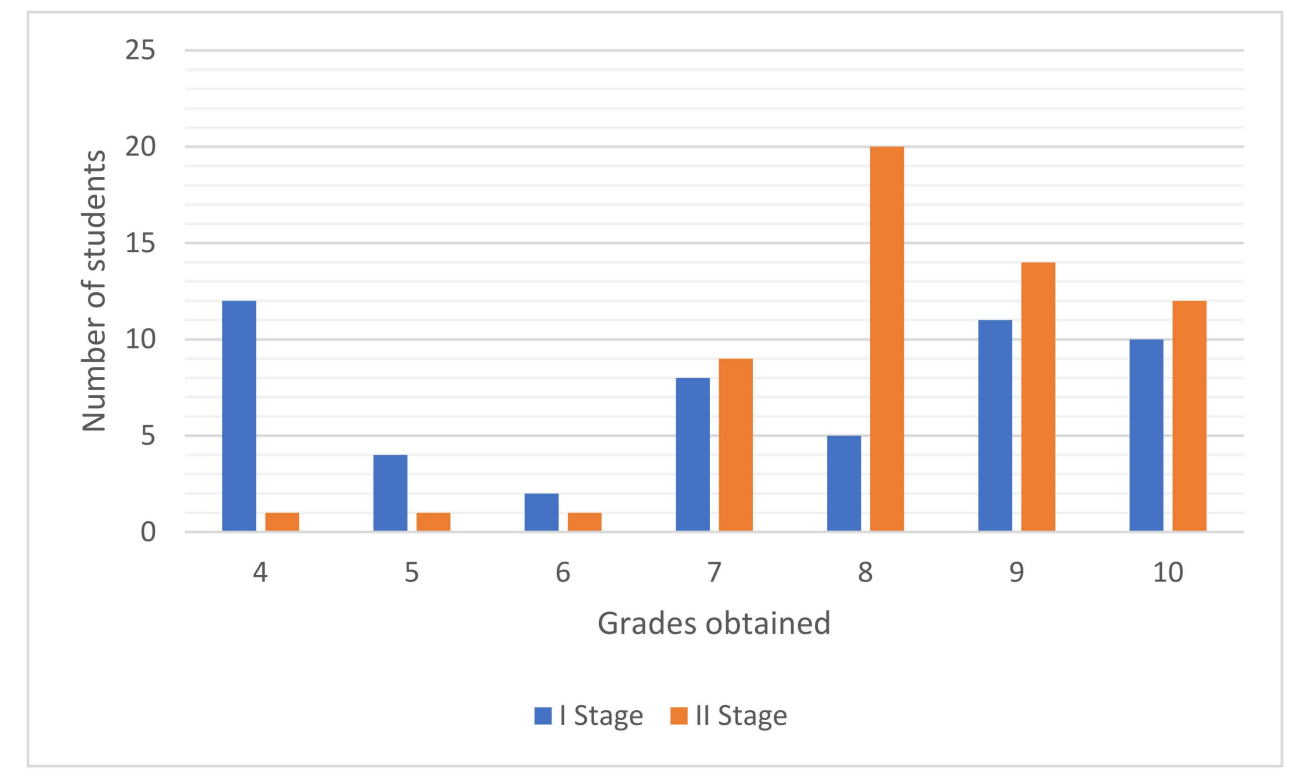

Figure 10. Analysis of exam results in stage I and II.

\section{Discussion and Conclusions}

Following the statistical analysis of the data obtained, it was observed that, in relation to well-being, in the post lockdown stage, the interest for other people correlates with optimism, relaxation and energy before the pandemic $(0.355$, correlation is significant at the 0.01 level), and interest in new things correlates negatively with interest in other people $(-0.300$, correlation is significant at the 0.01 level). The stronger the research participants had convictions before the pandemic, the harder it was for them to cope with the problems and feel good about themselves after the lockdown $(-0.314$, correlation is significant at the 0.01 level). Regarding the feedback provided by students, the values obtained in the first stage are positively correlated with those in the second stage $(0.584$, correlation is significant at the 0.01 level).

The well-being of students after quarantine increased at the group level, but there were much greater mood swings at the individual level. The increase may be due to the lifting of restrictions and the partial recovery of life before quarantine. Before the pandemic, the students' most frequent problems were lack of reserve energy and lack of relaxation, but they felt loved, were interested in new things, and were able to form their own opinions about things. After quarantine and isolation at home, the students stated that they had energy, but were not relaxed, so they felt a state of nervous tension, certainly due to the stress generated by COVID-19. It is interesting that the students did not feel as loved after quarantine, possibly either due to the lack of loved ones (because most said they still live with their parents and were at home in quarantine) or because they spent too much time with them. Thus, at the level of well-being, the lack of relaxation can be an indicator of the stress generated by the pandemic and the fluctuation of the state at the individual level, being several extreme values, very small and very high. Mood swings can be reactions to pandemics and quarantine, being part of states of anxiety, generated by stress and imbalances, due to the confrontation of the deepest areas of the human psyche with an extreme situation.

During online activities, students had more criticism on educational management, but also tended to have extremely positive opinions. A possible explanation could be that in the online environment, the capacity of the organization and management of the teacher's class is much more noticeable. At the same time, the negative feedback decreased for the activities in the online environment, due to the minimization of the problems related to the management of the team (telling people to be quiet, without conflicts between students, 
etc.), but also to the comparison with other teachers, who, as we said above, failed to carry out the activities optimally.

In the online environment, due to the restriction of the possibilities regarding the working methods, the analysis of the pedagogical item decreased, but the impact of the psychological item increased. In the online environment, with or without the students' camera on, they analyzed exclusively the person in front. In conclusion, online communication has several psychological ramifications, largely due to the cancellation of the other dimensions of the student-teacher relationship: they no longer share the same physical environment, there is no interference in communication, etc. In the online environment, students appreciated almost three times more the social relationship component, being eager for contact and social interaction.

During face-to-face activities, students also tend to analyze the teacher from the perspective of their personal development, so the degree of intimacy between participants is much higher.

Students' grades on exams increased by $16 \%$. A possible explanation would be the change in teaching and learning style, due to the online environment, but also the reduction of stress generated by face-to-face assessment. It is also possible to consider increasing the results of students by exam fraud, either by copying directly from the internet, which can be verified, or by accessing the materials on letter or electronic support during the exam. However, we do not consider that the increase in the exam marks is due to fraud, because the subjects also asked for open answers such as essays, which cannot be found on the internet, and thus, the hypothesis of fraud was eliminated. It is possible that online learning, through the methods used, has focused on key concepts, which were a better fit for students. Another essential element was the reduction of disturbances during the online interaction, more precisely the lack of noise and background noise that can interfere with the message sent, which certainly increased the disturbances in the environment of each participant.

For the teacher analysis, it seems to produce a strong, extremely positive feedback. Most of the students' recommendations are aimed at being able to better manage students' excessive speaking. A large part agrees with the methods used, but there are also research participants who would prefer different methods.

In conclusion, after the quarantine, all three analyzed parameters increased: wellbeing, feedback and learning outcomes. Releasing restrictions seems to have a much stronger impact on the personality than tension, stress and anxiety. Lifting restrictions and regaining mobility can generate a state of euphoria and optimism, which manifests itself not only on the well-being of the individual, but also influences their social perception, whether they see people around in a positive light, and their learning outcomes, and thus, implicitly influences the sustainability of the educational process. Optimism and euphoria, in the present research, have an impact on self-image and social perception. Other studies mentioned a correlation between optimism and social perception [72-74]. The explanation of the results obtained through the prism of optimism is also supported by the results of another study, conducted in Europe in 2020, according to which Romanians were the most optimistic people during the COVID-19 pandemic [75].

The results regarding the feedback for teaching activity are reinforced by the research carried out in another study, which also studied students from Sibiu, Romania, and which stated that students wanted to receive and provide feedback, and that they wanted their teacher to be attentive to their needs. This aspect is explicitly mentioned by the students in the present study, through statements such as: you are attentive to what we want, you give us feedback, I want you to tell us about how you see us, etc. [39]. The positive aspects identified by students participating in the study regarding the teacher's teaching activity coincide with the results of another study conducted in Romania [76,77], in which the following were mentioned as strengths: positive climate of understanding and responsibility, enthusiasm expressed in teaching, content and novelty, interactive, fun and creative teaching methods [78]. 


\section{Study Implications and Limitations}

One identified limitation of the study is the limited number of participants. Due to the small number of students in the sample, the conclusions cannot be generalized. However, to extend the study to a representative sample, a larger number of teachers would be needed to accept such an assessment, which is quite difficult to achieve. In the initial training of teachers, educational policies should be introduced to support not only the provision of feedback, but especially its reception, as a means of professional development $[79,80]$. The request for feedback should become an educational practice not only in the university environment, but also in pre-university education.

An interesting topic to study in the future could be the correlation between wellbeing and learning sustainability, as well as between optimism and learning sustainability. Another interesting topic to be addressed in future research can be the identification of what causes Romanians to have a high state of well-being and optimism, and why they are analysis-oriented towards activity sectors.

Author Contributions: Conceptualization, L.-I.C. and M.L.B.; methodology, L.-I.C. and M.L.B.; software, L.-I.C. and M.L.B.; validation, L.-I.C. and M.L.B.; formal analysis, L.-I.C. and M.L.B.; investigation, L.-I.C. and M.L.B.; resources, L.-I.C. and M.L.B.; data curation, L.-I.C. and M.L.B.; writing-original draft preparation, L.-I.C. and M.L.B.; writing-review and editing, L.-I.C. and M.L.B.; visualization, L.-I.C. and M.L.B.; supervision, L.-I.C. and M.L.B.; project administration, L.-I.C. and M.L.B.; funding acquisition, L.-I.C. All authors have read and agreed to the published version of the manuscript.

Funding: This research was funded by Lucian Blaga University of Sibiu \& Hasso Plattner Foundation research grants, grant number LBUS-IRG-2021-07. The APC was funded by Lucian Blaga University of Sibiu \& Hasso Plattner Foundation research grants.

Institutional Review Board Statement: Not applicable.

Informed Consent Statement: Informed consent was obtained from all subjects involved in the study.

Data Availability Statement: The data that support the findings of this study are openly available in: Cioca, Lucian Ionel; BRATU, MIHAELA LAURA (2021): Data underlying the research of social perception and well-being of students at the Faculty of Engineering from Sibiu, Romania. 4TU.ResearchData. Dataset. https://doi.org/10.4121/15066411.v1.

Conflicts of Interest: The authors declare no conflict of interest.

\section{References}

1. Toapanta, A.; Zea, D.; Tasiguano, C.; Anangano, G.; Prado, A.; Camacho, O. A review of autonomous vehicle technology and its use for the COVID-19 contingency. Cienc. Ing. 2021, 42, 43-51.

2. Robinson, P.; Johnson, P. Pandemic-Driven Technology Adoption: Public Decision Makers Need to Tread Cautiously. IJEPR 2021, 10, 59-65. [CrossRef]

3. Bricout, J.; Baker, P.; Moon, N.; Sharma, B. Exploring the Smart Future of Participation: Community, Inclusivity, and People With Disabilities. IJEPR 2021, 10, 94-108. [CrossRef]

4. Odendaal, N. Recombining Place: COVID-19 and Community Action Networks in South Africa. IJEPR 2021, 10, $124-131$. [CrossRef]

5. Uddin, M.M.; Akter, A.; Khaleduzzaman, A.B.M.; Sultana, M.N.; Hemme, T. Application of the Farm Simulation Model approach on economic loss estimation due to Coronavirus (COVID-19) in Bangladesh dairy farms-strategies, options, and way forward. Trop. Anim. Health Prod. 2021, 53, 33. [CrossRef]

6. Faour-Klingbeil, D.; Osaili, T.; Al-Nabulsi, A.; Jemni, M.; Todd, E. The public perception of food and non-food related risks of infection and trust in the risk communication during COVID-19 crisis: A study on selected countries from the Arab region. Food Control 2021, 121, 107617. [CrossRef]

7. Nakat, Z.; Bou-Mitri, C. COVID-19 and the food industry: Readiness assessment. Food Control 2021, 121, 107661. [CrossRef]

8. Briz-Redon, A.; Belenguer-Sapina, C.; Serrano-Aroca, A. Changes in air pollution during COVID-19 lockdown in Spain: A multi-city study. J. Environ. Sci. 2021, 101, 16-26. [CrossRef]

9. Liu, F.; Wang, M.; Zheng, M. Effects of COVID-19 lockdown on global air quality and health. Sci. Total Environ. 2021, 755, 142533. [CrossRef]

10. Urban, R.; Nakada, L. COVID-19 pandemic: Solid waste and environmental impacts in Brazil. Sci. Total Environ. 2021, 755, 142471. [CrossRef] 
11. Doyle, A.; Hynes, W.; Purcell, S. Building Resilient, Smart Communities in a Post-COVID Era: Insights From Ireland. IJEPR 2021, 10, 18-26. [CrossRef]

12. Paszto, V.; Burian, J.; Macku, K. Changing Mobility Lifestyle: A Case Study on the Impact of COVID-19 Using Personal Google Locations Data. IJEPR 2021, 10, 66-79. [CrossRef]

13. Dawson, A.; Dennis, S. Workplace Intimacy. Anthropol. Action 2021, 28, 1-7. [CrossRef]

14. Salas-Nicas, S.; Moncada, S.; Llorens, C.; Navarro, A. Working conditions and health in Spain during the COVID-19 pandemic: Minding the gap. Saf. Sci. 2021, 134, 105064. [CrossRef]

15. Al Falasi, B.; al Mazrouei, M.; al Ali, M.; al Dhamani, M.; al Ali, A.; al Kindi, M.; Dalkilinc, M.; al Qubaisi, M.; Campos, L.A.; al Tunaiji, H.; et al. Prevalence and Determinants of Immediate and Long-Term PTSD Consequences of Coronavirus-Related (CoV-1 and CoV-2) Pandemics among Healthcare Professionals: A Systematic Review and Meta-Analysis. Int. J. Environ. Res. Public Health 2021, 18, 2182. [CrossRef] [PubMed]

16. Chaimowitz, G.; Upfold, C.; Gea, L.; Qureshi, A.; Moulden, H.; Mamak, M.; Bradford, J. Stigmatization of psychiatric and justice-involved populations during the COVID-19 pandemic. Prog. Neuropsychopharmacol. Biol. Psychiatry 2021, 106, 110150. [CrossRef] [PubMed]

17. De Figueiredo, C.S.; Sandre, P.C.; Portugal, L.C.L.; de-Oliveira, T.M.; Chagas, L.d.S.; Raony, I.; Ferreira, E.S.; de-Araujo, E.G.; dos Santos, A.A.; Bomfim, P.O.S. COVID-19 pandemic impact on children and adolescents' mental health: Biological, environmental, and social factors. Prog. Neuropsychopharmacol. Biol. Psychiatry 2021, 106, 110171. [CrossRef]

18. Mallet, J.; Dubertret, C.; Strat, Y.L. Addictions in the COVID-19 era: Current evidence, future perspectives a com-prehensive review. Prog. Neuropsychopharmacol. Biol. Psychiatry 2021, 106, 110070. [CrossRef]

19. Driessen, A.; Borgstrom, E.; Cohn, S. Ways of 'Being With' Caring for Dying Patients at the Height of the COVID-19 Pandemic. Anthropol. Action 2021, 28, 16-20. [CrossRef]

20. Paredes, M.R.; Apaolaza, V.; Fernandez-Robin, C.; Hartmann, P.; Yanez-Martinez, D. The impact of the COVID-19 pandemic on subjective mental well-being: The interplay of perceived threat, future anxiety and resilience. Pers. Individ. Differ. 2021, 170, 110455. [CrossRef]

21. Bassi, M.; Negri, L.; Delle Fave, A.; Accardi, R. The relationship between post-traumatic stress and positive mental health symptoms among health workers during COVID-19 pandemic in Lombardy, Italy. J. Affect. Disord. 2021, 280, 1-6. [CrossRef]

22. Zandi, G.R.; Shahzad, I.; Farrukh, M.; Kot, S. Supporting Role of Society and Firms to COVID-19 Management among Medical Practitioners. Int. J. Environ. Res. Public Health 2020, 17, 7961. [CrossRef] [PubMed]

23. Otterbring, T.; Festila, A.; Folwarczny, M. Replication and extension of framing effects to compliance with health behaviors during pandemics. Saf. Sci. 2021, 134, 105065. [CrossRef]

24. Iancheva, T. Psychological consequences of self-isolation and online education of sports students during a pandemic. Pedagogika 2020, 92, 152-162.

25. Orgiles, M.; Morales, A.; Delvecchio, E.; Mazzeschi, C.; Espada, J.P. Immediate Psychological Effects of the COVID-19 Quarantine in Youth From Italy and Spain. Front. Psychol. 2020, 11, 2986. [CrossRef] [PubMed]

26. Gilligan, M.; Suitor, J.J.; Rurka, M.; Silverstein, M. Multigenerational social support in the face of the COVID-19 pandemic. J. Fam. Theory Rev. 2020, 12, 431-447. [CrossRef]

27. Isumi, A.; Doi, S.; Yamaoka, Y.; Takahashi, K.; Fujiwara, T. Do suicide rates in children and adolescents change during school closure in Japan? The acute effect of the first wave of COVID-19 pandemic on child and adolescent mental health. Child Abuse Negl. 2020, 110, 104680. [CrossRef] [PubMed]

28. McKenzie, L. Shutting Down Sex COVID-19, Sex and the Transformation of Singledom. Anthropol. Action 2020, 27, 9-13. [CrossRef]

29. Edwards, E.; Janney, C.A.; Mancuso, A.; Rollings, H.; VanDenToorn, A.; DeYoung, M.; Halstead, S.; Eastburg, M. Preparing for the Behavioral Health Impact of COVID-19 in Michigan. Curr. Psychiatry Rep. 2020, 22, 88. [CrossRef]

30. Larcher, V.; Dittborn, M.; Linthicum, J.; Sutton, A.; Brierley, J.; Payne, C.; Hardy, H. Young people's views on their role in the COVID-19 pandemic and society's recovery from it. Arch. Dis. Child. 2020, 105, 1192-1196. [CrossRef]

31. Irimie, S. Evaluarea Stării de Bine a Copilului; Institutul Naţional de Sănătate Publică: Bucharest, Romania, 2017.

32. Avram, E.; Cooper, C.L. Psihologie Organizațional-Managerială. Tendințe Actuale; Polirom: Iași, Romania, 2008.

33. Virga, D.; Iliescu, D. The well-being of Romanian workers in Spain: Antecedents and moderators. Eur. J. Work. Organ. Psychol. 2017, 26, 149-159. [CrossRef]

34. Mag, A.G. Promoting Children's Wellbeing. Policies, Practices and Current Trends. Procedia Soc. Behav. Sci. 2015, 180, 1391-1397. [CrossRef]

35. Baron, B. Social Psychology—Understanding Human Interaction, 6th ed.; Allyn \& Bacon: Boston, MA, USA, 1991.

36. Cihodariu, M. Petru Ilut, Psihologie socială și sociopsihologie, Iași, Editura Polirom. Sociol. Rom. 2010, 8, $178-181$.

37. Coteanu, I. Dictionarul Explicativ al Limbii Române; Editura Universitara: Bucharest, Romania, 2016 ; ISBN 9786067041613.

38. Smile Media. Hot News. Tot ce Trebuie să Știi Despre Mirro, Aplicația Care Crește Performanța Echipelor în Remote-Work și nu Numai. Available online: https:/ / www.hotnews.ro/stiri-esential-24428740-tot-trebuie-stii-despre-mirro-aplicatia-care-cresteperformanta-echipelor-remote-work-nu-numai.htm (accessed on 18 March 2021).

39. Mag, A.G. The value of students' feedback. In Proceedings of the 9th International Conference on Manufacturing Science and Education (MSE 2019): Trends In New Industrial Revolution, Sibiu, Romania, 5-7 June 2019; p. 290. [CrossRef] 
40. Jones, P. Rethinking Childhood: Attitudes in Contemporary Society; Continuum International Publishing Group: New York, NY, USA, 2009.

41. Pantazi, R. Top 5 Măsuri Educaționale Cu Impact. Dragoș Iliescu, Expert În Testare: Sunt Școli Care Ignoră Știința Și Merg pe o Ideologie de Genul "Să Lăsăm Copiii Să Devină ce Vor, Să Nu Îi Forțăm Și Anxietăm". Available online: https: / / www.edupedu.ro/top-5-masuri-educationale-cu-impact-asupra-invatarii-dragos-iliescu-expert-in-psihometriesunt-scoli-care-ignora-dovezile-stiintifice-mergand-pe-o-ideologie-de-genul-sa-lasam-copiii-sa-devina-ce/ (accessed on 18 March 2021).

42. Bratu, M.L.; Cioca, L.I. Adaptation of managerial style to the personality of engineers, in order to increase performance in the workplace. Pol. J. Manag. Stud. 2018, 17, 67-77. [CrossRef]

43. Bratu, M.L.; Cioca, L.I. Managerial strategies of the personal values, used to improve engineers communication. In Proceedings of the 9th International Conference On Manufacturing Science And Education (MSE 2019): Trends in New Industrial Revolution, Sibiu, Romania, 5-7 June 2019; p. 290. [CrossRef]

44. Administrare.Info. Imaginea de Sine Şi Percepţia Socială. Available online: https://administrare.info/domenii/administra\%C8 \%9Bie-public\%C4\%83/50-imaginea-de-sine-\%C5\%9Fi-percep\%C5\%A3ia-social\%C4\%83 (accessed on 18 March 2021).

45. Siru, A. Imaginea de Sine-Stima de Sine si Increderea in Sine. Centrul Medical de Diagnostic si Tratament "Dr. Victor Babes". Available online: https://www.cdt-babes.ro/articole/imaginea-de-sine-stima-de-sine-si-increderea-in-sine.php (accessed on 18 March 2021).

46. United Nations. Report of the United Nations Conference on Environment and Development, Rio de Janeiro, 1992; United Nations: New York, NY, USA, 1993; Available online: https:/ / www.un.org/esa/dsd/agenda21/Agenda\%2021.pdf (accessed on 28 March 2021).

47. Bratu, I.A. Digitizing maps procedure for scientific forestry administration by GIS database. Case study: Rasinari forestry administration. In Proceedings of the International Conference on Energy and Environment (CIEM), Timisoara, Romania, 17-18 October 2019; pp. 95-98. [CrossRef]

48. Bratu, I.A. Using GIS for sustainable forest management in Rasinari District, Sibiu County, Romania. In Proceedings of the Informatics, Geoinformatics and Remote Sensing Conference, Albena, Bulgaria, 30 June-6 July 2016; Volume 3.

49. Blada, I.; Tanasie, S.; Dinu, C.; Bratu, I.A. Growth, straightness and survival at age 32 in a Pinus strobus $\times$ P. wallichiana F-1 hybrid population (Experiment 1). Ann. For. Res. 2013, 56, 269-282.

50. Bratu, I.A. Open source solutions to improve the quality of sustainable forest management. MATEC Web Conf. 2019, 290, 11003. [CrossRef]

51. Enescu, C.M.; Dinca, L.; Bratu, I.A. Chemical characteristics of the forest soils from Prahova County. In Scientific Papers Series "Management, Economic Engineering in Agriculture and Rural Development"; University of Agricultural Sciences and Veterinary Medicine: Bucharest, Romania, 2018; Volume 18, pp. 109-112.

52. Stanciu, M.C. Research regarding younger consumers attitude, in relation with sheep meat consumption. In Scientific Papers Series "Management, Economic Engineering in Agriculture and Rural Development"; University of Agricultural Sciences and Veterinary Medicine: Bucharest, Romania, 2020; Volume 20, pp. 125-130.

53. Rogoio, M.; Nishijima, T. The right to the sustainable environment though environmental education focused on the rational use of the rural property and the fulfillment of its social role. Veredas Direito 2015, 12, 235-258.

54. Benjumeda, F; Romero, I. Sustainable Town: A project for integrating science, mathematics and technology at secondary school. Rev. Eureka 2017, 14, 621-637. [CrossRef]

55. Grabelnikov, A.A.; Gegelova, N.S.; Osipovskaya, E.A.; Ott, V.S. Journalism education in the context of COVID-19 pandemic: Pros and cons. Theor. Pract. Issues J. 2020, 9, 713-726. [CrossRef]

56. Ropero-Padilla, C.; Rodriguez-Arrastia, M.; Martinez-Ortigosa, A.; Salas-Medina, P.; Ayora, A.F.; Roman, P. A gameful blendedlearning experience in nursing: A qualitative focus group study. Nurse Educ. Today 2021, 106, 105109. [CrossRef]

57. Rodic, M.V.; Rodic, D.D. Plans vs Reality: Reflections on Chemical Crystallography Online Teaching During COVID-19. J. Chem. Educ. 2020, 97, 3038-3041. [CrossRef]

58. Mukhopadhyay, S.; Joshi, D.; Goel, G.; Singhai, A.; Kapoor, N. Evolution of pathology teaching for MBBS students during COVID-19 pandemic lockdown: Moving from a real to a virtual classroom. Indian J. Pathol Microbiol. 2021, 64, 524-527. [PubMed]

59. Narang, U.; Yadav, M.S.; Rindfleisch, A. The "Idea Advantage": How Content Sharing Strategies Impact Engagement in Online Learning Platforms. J. Mark. Res. 2021, 00222437211017828. [CrossRef]

60. Basal, A.; Eryilmaz, A. Engagement and affection of pre-service teachers in online learning in the context of COVID 19: Engagement-based instruction with web 2.0 technologies vs direct transmission instruction. J. Educ. Teach. 2021, 47, 131-133. [CrossRef]

61. Brockman, R.M.; Taylor, J.M.; Segars, L.W.; Selke, V.; Taylor, T.A.H. Student perceptions of online and in-person microbiology laboratory experiences in undergraduate medical education. Med. Educ. Online 2020, 25, 1710324. [CrossRef]

62. Costado Dios, M.T.; Piñero Charlo, J.C. Face-to-Face vs. E-Learning Models in the COVID-19 Era: Survey Research in a Spanish University. Educ. Sci. 2021, 11, 293. [CrossRef]

63. Pevneva, I.; Edmunds, P. Online Learning vs. Extreme Learning in Mining Higher Education under COVID. E3S Web Conf. 2020, 174, 04001. [CrossRef]

64. Morsi, W.K.; Assem, H.M. Online versus Face-to-face Collaborative Learning: Perceptions of Students and Instructors of Technical Writing for Engineers. In Proceedings of the 2021 IEEE Global Engineering Education Conference (EDUCON), Vienna, Austria, 21-23 April 2021; pp. 1577-1587. 
65. Gherhes, V.; Stoian, C.E.; Farcasiu, M.A.; Stanici, M. E-Learning vs. Face-To-Face Learning: Analyzing Students' Preferences and Behaviors. Sustainability 2021, 13, 4381. [CrossRef]

66. Neamtu, N.; Faludi, C. Learning Effectiveness of Social Work Methods With Groups, in Online and Face-to-Face Contexts. Front. Psychol. 2021, 12, 649691. [CrossRef]

67. Warwick Medical School, “University of Warwick”. Available online: https://warwick.ac.uk/fac/sci/med/research/platform/ wemwbs/researchers/languages/frequent_issues_in_translation.pdf (accessed on 15 November 2017).

68. International Test Commission. The ITC Guidelines for Translating and Adapting Tests, 2nd ed. 2017. Available online: https:/ /www.intestcom.org/files/guideline_test_adaptation_2ed.pdf (accessed on 2 February 2020).

69. Bratu, M.L. Adaptarea Sistemului de Management și a Ergonomiei Din Organizații la Trăsăturile de Personalitate ale Inginerilor, 1st ed.; Editura Universitara: Bucharest, Romania, 2020.

70. Miralles, F.; Garcia, H. Ikigai Method. Japanese Secrets to Discover Your True Passion, 1st ed.; Humanitas: Bucharest, Romania, 2019.

71. DeLong, T.J. Three Questions for Effective Feedback. Harvard Business Review. Available online: https://hbr.org/2011/08/ three-questions-for-effective-feedback (accessed on 11 January 2020).

72. Manige, H.; Papi, S.; Sahaf, R.; Asl, M.; Ramshini, M.; Rassafiani, M.; Bodaghi, A. Predicting the Perception of Aging Based on Optimism in the Elderly People. Iran. J. Ageing 2020, 14, 450-460.

73. Supervia, P.U.; Bordas, C.S.; Lorente, V.M. Exploring the Psychological Effects of Optimism on Life Satisfaction in Students: The Mediating Role of Goal Orientations. Int. J. Environ. Res. Public Health 2020, 17, 7887. [CrossRef] [PubMed]

74. Cnen, T.W.; Chiu, Y.C.; Hsu, Y. Perception of social support provided by coaches, optimism/pessimism, and psychological well-being: Gender differences and mediating effect models. Int. J. Sports Sci. Coach. 2020, 16, 272-280. [CrossRef]

75. Stroescu, A. Românii Sunt Cei Mai Optimiști Europeni în Timpul Pandemiei de COVID-19. Mediafax. Available online: https: //www.mediafax.ro/social/romanii-sunt-cei-mai-optimisti-europeni-in-timpul-pandemiei-de-covid-19-19754611 (accessed on 25 August 2020).

76. Moraru, G.M.; Popescu, L.G. Quality versus quantity in the academics' evaluation. In Proceedings of the 11th International Technology, Education and Development Conference, Valencia, Spain, 6-8 March 2017; pp. 1777-1783.

77. Grecu, V.; Denes, C.; Ipina, N. Creative Teaching Methods for Educating Engineers. Appl. Mech. Mater. 2013, 371, 764-768. [CrossRef]

78. Cioca, L.I.; Nerisanu, R.A. Enhancing Creativity: Using Visual Mnemonic Devices in the Teaching Process in Order to Develop Creativity in Students. Sustainability 2020, 12, 1985. [CrossRef]

79. Nicu, A. The Importance of Mastering Pedagogy Knowledge in Initial Teacher Training. In Proceedings of the Edu World 7th International Conference, Pitesti, Romania, 4-5 November 2016; Volume 23, pp. 772-780.

80. Nicu, A. Policy and Practice of Initial Teacher Training. In Proceedings of the 6th International Conference Edu World 2014 "Education Facing Contemporary World Issues", Pitesti, Romania, 7-9 November 2014; pp. 80-86. 